\title{
Penyelesaian Perkara Perdata di Pengadilan Berdasarkan Peraturan Mahkamah Agung Republik Indonesia Nomor 1 Tahun 2016
}

\author{
I Komang Wiantara ${ }^{1}$ \\ ${ }^{1}$ Program Studi Magister Ilmu Hukum, Fakultas Hukum, Universitas Udayana, \\ E-mail: komangwiantara52@gmail.com
}

\begin{tabular}{l}
\hline Info Artikel \\
\hline Masuk: 7 Oktober 2018 \\
Diterima: 17 Desember 2018 \\
Terbit: 31 Desember 2018 \\
Keywords : \\
Mediation; Case Settlement; \\
Court \\
\\
\\
Kata kunci: \\
Mediasi; Penyelesaian Perkara; \\
Pengadilan \\
Corresponding Author: \\
I Komang Wiantara, \\
E-mail: \\
komangwiantara52@gmail.com \\
DOI : \\
10.24843/JMHU.2018.v07.i04. \\
p04
\end{tabular}

\begin{abstract}
The existence of mediation in the settlement of civil disputes in the courts is regulated in the Supreme Court Regulation No. 1 of 2016 concerning Mediation Procedures in the Court which contains ten principles including: mediation must be taken, party autonomy, mediation in good faith, time efficiency, mediator certification, mediator responsibility, confidentiality, financing, repetition of mediation, peace agreements outside the court, become integral parts in resolving disputes in court. In addition, mediation in the court strengthened peaceful efforts as stated in the Civil Procedure Code. The purpose of this study is to understand and analyze the legal strength of mediation in the Court. This study uses a normative juridical research method using the statutory approach. Study show that due to its consensual and collaborative nature, mediation always results in a dispute resolution in a win-win solution that is strengthened to become a Peace Deed, which has Executorial power like a Court Decision.
\end{abstract}

\section{Abstrak}

Eksistensi mediasi dalam penyelesaian sengketa perdata di pengadilan diatur dalam Peraturan Mahkamah Agung Republik Indonesia Nomor 1 Tahun 2016 Tentang Prosedur Mediasi Di Pengadilan yang memuat sepuluh prinsip meliputi: mediasi wajib ditempuh, otonomi para pihak, mediasi dengan itikad baik, efisiensi waktu, sertifikasi mediator, tanggung jawab mediator, kerahasiaan, pembiayaan, pengulangan mediasi, kesepakatan perdamaian di luar pengadilan, menjadi bagian dalam integral dalam penyelesaian sengketa di pengadilan. Selain itu mediasi pada pengadilan memperkuat upaya damai sebagaimana yang tertuang di dalam hukum acara Perdata. Tujuan penelitian ini untuk memahami dan menganalisis kekuatan hukum mediasi menurut Peraturan Mahkamah Agung Republik Indonesia Nomor 1 Tahun 2016 Tentang Prosedur Mediasi Di Pengadilan. Kajian ini menggunakan metode penelitian yuridis normatif dengan menggunakan pendekatan perundang-undangan. Hasil penelitian menunjukkan bahwa karena sifatnya yang konsensual dan kolaboratif, 
maka mediasi selalu menghasilkan penyelesaian sengketa dengan cara sama-sama menguntungkan bagi para pihak (win-win solution) yang dikuatkan menjadi Akta Perdamaian, yang memiliki kekuatan Eksekutorial layaknya Putusan Pengadilan.

\section{Pendahuluan}

Kedudukan peradilan sebagai pelaksana kekuasaan kehakiman dalam negara hukum mempunyai peran sebagai pressure valve terhadap setiap pelanggaran hukum dan ketertiban masyarakat, oleh karena itu peradilan masih diandalkan sebagai badan yang memiliki fungsi dan berperan menegakkan kebenaran dan keadilan dalam menangani kasus-kasus harus berdasarkan pada prinsip perlakuan dan dengan cara yang jujur (fair manner) dan benar ${ }^{1}$. Dalam perkara perdata yang di dalamnya terdapat sengketa dan diajukan oleh pihak penggugat ke pengadilan, maka akan diselesaikan dan diputus oleh pengadilan. Pada sidang pertama hakim wajib mengupayakan perdamaian sebagaimana ditentukan oleh Pasal 130 HIR.

Integrasi mediasi di pengadilan sudah dimulai pada tahun 2003 yang telah beberapa kali direvisi hingga diterbitkannya Peraturan Mahkamah Agung Republik Indonesia Nomor 1 Tahun 2016 Tentang Prosedur Mediasi Di Pengadilan (selanjutnya disebut PERMA No. 1 Tahun 2016). Kebijakan ini pada dasarnya lebih dimaksudkan untuk mengatur prinsip dan prosedur penggunaan mediasi terhadap perkara atau sengketa perdata yang telah diajukan ke pengadilan (court connected mediation). Namun untuk lebih memperkuat penggunaan mediasi dalam sistem hukum Indonesia dan memperkecil timbulnya persoalan-persoalan hukum yang mungkin timbul dari penggunaan mediasi di luar pengadilan, PERMA No. 1 Tahun 2016 tersebut juga memuat ketentuan yang dapat digunakan oleh pihak-pihak yang bersengketa yang berhasil menyelesaikan sengketa melalui mediasi di luar pengadilan untuk meminta kepada pengadilan agar kesepakatan damai di luar pengadilan dikuatkan dengan akta perdamaian sebagaimana yang tertuang dalam Pasal 27 ayat (4) yakni "Para Pihak melalui Mediator dapat mengajukan Kesepakatan Perdamaian kepada Hakim Pemeriksa Perkara agar dikuatkan dalam Akta Perdamaian".

Mediasi di luar Pengadilan tidak jauh berbeda dengan mediasi di Pengadilan. Perbedaannya terletak pada kesepakatan yang akan dicapai dan dilaksanakan oleh para pihak. Bila telah tercapai kesepakatan bentuk perjanjian tertulis di atas kertas bermeterai, yang ditandatangani oleh para pihak dan mediator. Dalam kurun waktu paling lama 30 (tiga puluh) hari terhitung sejak tanggal ditandatangani kesepakatan tersebut, maka lembaran asli atau salinan autentik kesepakatan diserahkan dan didaftarkan pada Panitera Pengadilan Negeri. Penyerahan atau pendaftaran salinan autentik kesepakatan dilakukan oleh mediator atau salah satu pihak atau para pihak yang bersengketa. Jika salah satu pihak melanggar isi kesepakatan, maka tidak diperkenankan meminta eksekusi kepada Pengadilan, melainkan harus mengajukan

1 Sari, I. M. Persamaan Perlakuan Para Pihak dalam Beracara di KPPU Dalam Perspektif Hukum Acara Peradilan Indonesia. Jurnal Magister Hukum Udayana (Udayana Master Law Journal), 5(2), 380-391. https:// doi.org/10.24843/JMHU.2016.v05.i02.p12. 
gugatan terlebih dahulu. Lain halnya dengan mediasi di pengadilan yang mempunyai kekuatan eksekutorial sehingga dapat dimintai eksekusi.

PERMA No. 1 Tahun 2016 menjadi bagian dalam integral dalam penyelesaian sengketa di pengadilan. Selain itu mediasi pada pengadilan memperkuat upaya damai sebagaimana yang tertuang di dalam hukum acara Pasal 130 HIR atau Pasal 154 Rechtsreglement voor de Buitengewesten (Selanjutnya disebut RBg). Hal ini ditegaskan dalam Pasal 4 ayat (1) PERMA No. 1 Tahun 2016, yaitu "Semua sengketa perdata yang diajukan ke Pengadilan termasuk perkara perlawanan (verzet) atas putusan verstek dan perlawanan pihak berperkara (partij verzet) maupun pihak ketiga (derden verzet) terhadap pelaksanaan putusan yang telah berkekuatan hukum tetap, wajib terlebih dahulu diupayakan penyelesaian melalui Mediasi, kecuali ditentukan lain berdasarkan Peraturan Mahkamah Agung ini". Kasus-kasus dalam wilayah privat/perdata misalnya sengketa mengenai kepemilikan, mengenai waris, dan mengenai bisnis yang diajukan ke pengadilan tingkat pertama wajib untuk diselesaikan lewat proses mediasi dengan bantuan mediator sesuai dengan PERMA No. 1 Tahun 2016 di dalam pasal 3 ayat (1) yang bunyinya: "Setiap Hakim, Mediator, Para Pihak dan/atau kuasa hukum wajib mengikuti prosedur penyelesaian sengketa melalui Mediasi".

Keseharian yang terjadi di peradilan, meskipun proses penyelesaian sengketa dilaksanakan dengan berlandaskan pada Pasal 2 ayat (4) Undang-Undang Republik Indonesia Nomor 48 Tahun 2009 Tentang Kekuasaan Kehakiman yakni "Peradilan dilakukan dengan sederhana, cepat, dan biaya ringan", kemudian pengadilan telah memeriksa dengan memutuskan perkara secara tepat berdasarkan hukum dan adil, tetapi oleh hukum masih memberikan ruang bagi pihak yang kalah untuk menggunakan upaya hukum karena para pihak merasa keputusan yang dikeluarkan tidak adil. Dengan adanya mediasi di pengadilan dapat membantu para pihak dalam menyelesaikan sengketa dengan adil sesuai dengan kehendak masing-masing, tanpa harus ada menang dan kalah. Disamping itu penyelesaian sengketa melalui mediasi di pengadilan jika berhasil dilaksanakan memiliki kekuatan eksekutorial sehingga para pihak harus menjaga dan melaksanakan apa yang telah disepakati bersama yang tertuang di dalam akte perdamaian. Kekuatan hukum akta perdamaian dikuatkan dalam bentuk putusan yang mana putusan tersebut dimuat di dalam akta perdamaian yang berbentuk surat perjanjian dari para pihak yang sepakat untuk membuat perjanjian tersebut dihadapan mediator hal ini menyiratkan dalam Pasal 1338 KUHPerdata yakni "Semua persetujuan yang dibuat sesuai dengan undang-undang berlaku sebagai undang-undang bagi mereka yang membuatnya. Persetujuan itu tidak dapat ditarik kembali selain dengan kesepakatan kedua belah pihak, atau karena alasan-alasan yang ditentukan oleh undangundang, Persetujuan harus dilaksanakan dengan itikad baik".

Berdasarkan pemaparan latar belakang diatas, maka dapat dikemukakan permasalahan yang akan dikaji dalam tulisan ini yaitu Bagaimanakah eksistensi mediasi dalam penyelesaian perkara perdata di pengadilan? Dan Bagaimanakah kekuatan hukum mediasi selama proses penyelesaian perkara perdata di Pengadilan? Tulisan ini bertujuan untuk menganalisis eksistensi mediasi menurut Peraturan Mahkamah Agung Republik Indonesia Nomor 1 Tahun 2016 Tentang Prosedur Mediasi Di Pengadilan. Tujuan selanjutnya untuk memahami dan menganalisis kekuatan hukum mediasi menurut Peraturan Mahkamah Agung Republik Indonesia Nomor 1 Tahun 2016 Tentang Prosedur Mediasi Di Pengadilan. Adapun beberapa 
penelitian yang juga mengangkat isu mengenai mediasi di Pengadilan dapat dilihat dalam tulisan Edmond Hendrikus Bisara pada tahun 2017 yang berjudul Penyelesaian Sengketa Melalui Mediasi Di Dalam Pengadilan², dan Bintoro pada tahun 2016 yang berjudul Kajian Ontologis Lembaga Mediasi Di Pengadilan ${ }^{3}$.

\section{Metode Penelitian}

Kajian ini menggunakan metode penelitian yuridis normatif. Penelitian ini mengkaji bahan kepustakaan terdiri dari bahan hukum dan ditunjang oleh bahan hukum sekunder yang menyangkut penelitian secara menyeluruh baik diantara peraturan setingkat atau di atasnya dimana obyek kajiannya adalah dokumen-dokumen peraturan-peraturan hukum serta bahan-bahan pustaka, suatu peraturan perundangundangan yang tergolong dalam bahan hukum primer dengan meneliti Peraturan Mahkamah Agung Republik Indonesia Nomor 1 Tahun 2016 Tentang Prosedur Mediasi Di Pengadilan. Pendekatan yang digunakan dalam penelitian ini yaitu pendekatan perundang-undangan. Teknik pengumpulan bahan hukum dalam penelitian ini menggunakan snowball method (metode bola salju) ${ }^{4}$. Teknik analisis bahan hukum yang digunakan adalah teknik deskripsi, dengan digunakannya teknik ini peneliti menguraikan secara apa adanya terhadap suatu kondisi atau posisi dan proposisi-proposisi hukum atau non-hukum.

\section{Hasil dan Pembahasan}

\subsection{Eksistensi Mediasi Dalam Penyelesaian Sengketa Perdata Di Pengadilan}

Berdasarkan ketentuan Pasal 4 PERMA Nomor 1 Tahun 2016, semua perkara perdata yang di yang diajukan wajib diupayakan penyelesaian melalui perundingan dengan bantuan mediator. Sedangkan pemeriksaan perkara sengketa niaga, hubungan industrial, perlindungan konsumen dan persaingan usaha telah diatur dengan prosedur tersendiri, meskipun perkara itu termasuk dalam kategori perdata, tetapi dikecualikan dari kewajiban untuk menempuh proses mediasi sebagaimana diatur dalam Perma Nomor 1 Tahun 2016. Dalam PERMA No. 1 Tahun 2016 memuat sepuluh prinsip pengaturan tentang menggunakan mediasi terintegrasi di pengadilan (courtconnected mediation). Sepuluh prinsip tersebut adalah sebagai berikut:

1. Mediasi wajib ditempuh,

Sebelum sengketa diputus oleh hakim para pihak wajib terlebih dahulu menempuh mediasi. Jika proses mediasi tidak ditempuh atau sebuah sengketa langsung diperiksa dan diputus oleh hakim, konsekwensi hukumnya adalah putusan itu batal demi hukum. Ketentuan ini terdapat dalam Pasal 2 ayat (3) PERMA Nomor 1 Tahun 2016.

2. Otonomi para pihak,

Prinsip otonomi para pihak merupakan prinsip yang melekat pada proses mediasi. Karena dalam mediasi para pihak berpeluang yang menentukan dan

2 Matarau, E. H. B. (2017). Penyelesaian Sengketa Melalui Mediasi di dalam Pengadilan. Jurnal Kertha Wicaksana, 1(6).

3 Bintoro, R. W. (2016). Kajian Ontologis Lembaga Mediasi di Pengadilan. Yuridika, 31(1), 121142. http://dx.doi.org/10.20473/ydk.v31i1.1959

4 Djam'an, S., \& Komariah, A. (2010). Metodologi Penelitian Kualitatif. Bandung: Alfabeta. h. 18. 
mempengaruhi proses dan hasilnya berdasarkan mekanisme konsensus atau mufakat para pihak dengan bantuan pihak netral.

3. Mediasi dengan itikad baik,

Mediasi merupakan proses penyelesaian sengketa melalui musyawarah mufakat atau konsensus para pihak yang akan dapat berjalan dengan baik jika dilandasi oleh iktikad untuk menyelesaikan sengketa.

4. Efisiensi waktu,

Masalah waktu merupakan salah satu faktor penting dalam menyelesaikan sebuah sengketa atau perkara. Prinsip efisiensi waktu dalam PERMA Nomor 1 Tahun 2016 ini tampak pada pengaturan pembatasan waktu bagi para pihak dalam perundingan untuk memilih mediator diantara pilihan sebagaimana disebutkan dalam Pasal 3 ayat (6).

5. Sertifikasi mediator,

PERMA Nomor 1 Tahun 2016 mendorong lahirnya mediator-mediator profesional. Mediator wajib memiliki sertifikat mediator yang diperoleh setelah mengikuti pelatihan yang diselenggarakan oleh lembaga yang telah memperoleh akreditasi dari Mahkamah Agung Republik Indonesia.

6. Tanggung Jawab Mediator,

Mediator memiliki tugas dan tanggung jawab yang bersifat prosedural dan fasilitatif. Tugas-tugas ini tercermin dalam ketentuan Pasal 14 PERMA Nomor 1 Tahun 2016 yaitu:

- memperkenalkan diri dan memberi kesempatan kepada Para Pihak untuk saling memperkenalkan diri;

- menjelaskan maksud, tujuan, dan sifat Mediasi kepada Para Pihak;

- menjelaskan kedudukan dan peran Mediator yang netral dan tidak mengambil keputusan;

- membuat aturan pelaksanaan Mediasi bersama Para Pihak;

- menjelaskan bahwa Mediator dapat mengadakan pertemuan dengan satu pihak tanpa kehadiran pihak lainnya (kaukus);

- menyusun jadwal Mediasi bersama Para Pihak;

- mengisi formulir jadwal mediasi;

- memberikan kesempatan kepada Para Pihak untuk menyampaikan permasalahan dan usulan perdamaian; menginventarisasi permasalahan dan mengagendakan pembahasan berdasarkan skala prioritas;

- memfasilitasi dan mendorong Para Pihak untuk: 1. menelusuri dan menggali kepentingan Para Pihak; 2. mencari berbagai pilihan penyelesaian yang terbaik bagi Para Pihak; dan 3. bekerja sama mencapai penyelesaian; membantu Para Pihak dalam membuat dan merumuskan Kesepakatan Perdamaian;

- menyampaikan laporan keberhasilan, ketidakberhasilan dan/atau tidak dapat dilaksanakannya Mediasi kepada Hakim Pemeriksa Perkara;

- menyatakan salah satu atau Para Pihak tidak beriktikad baik dan menyampaikan kepada Hakim Pemeriksa Perkara; dan tugas lain dalam menjalankan fungsinya ${ }^{5}$.

5 Hidayat, Maskur. 2016. Strategi Dan Taktik Mediasi. Jakarta:. Kencana. h. 220. 
7. Kerahasiaan, berbeda dengan proses litigasi yang bersifat terbuka untuk umum, proses mediasi pada asasnya tertutup bagi umum kecuali para pihak menghendaki lain.

8. Pembiayaan,

Pembiayaan yang berkaitan dengan proses mediasi paling tidak mencakup halhal sebagai berikut: ketersediaan ruang-ruang mediasi, honor para mediator, biaya para ahli jika diperlukan, dan biaya transport para pihak yang datang ke pertemuan-pertemuan atau sesi-sesi mediasi.

9. Pengulangan mediasi

Pasal 17 ayat (1) PERMA Nomor 1 Tahun 2016, memberikan kewenangan kepada hakim pemeriksa perkara untuk tetap mendorong para pihak supaya menempuh perdamaian setelah kegagalan proses mediasi pada tahap awal atau pada tahap sebelum pemeriksaan perkara dimulai.

10. Kesepakatan perdamaian di luar pengadilan,

PERMA Nomor 1 Tahun 2016 pada dasarnya lebih dimaksudkan untuk mengatur prinsip dan prosedur penggunaan mediasi terhadap perkara atau sengketa perdata yang telah diajukan ke pengadilan (court-connected mediation).Namun, sebagai upaya untuk lebih memperkuat penggunaan mediasi dalam sistem hukum Indonesia dan memperkecil timbulnya persoalanpersoalan hukum yang mungkin timbul dari penggunaan mediasi di luar pengadilan, Mahkamah Agung Melalui PERMA Nomor 1 Tahun 2016 juga memuat ketentuan yang dapat digunakan oleh pihak-pihak bersengketa yang berhasil menyelesaikan sengketa itu melalui mediasi di luar pengadilan untuk meminta pengadilan agar kesepakatan damai di luar pengadilan dikuatkan dengan akta perdamaian.

Penerbitan PERMA Nomor 1 Tahun 2016 bertujuan untuk mengoptimalkan proses penyelesaian sengketa secara damai yang bertujuan untuk mencari kebenaran formilnya dalam perkara perdata ${ }^{6}$. Terdapat beberapa alasan yang melatarbelakangi upaya integrasi lembaga perdamaian di pengadilan:

1. Untuk mengatasi penumpukan perkara di pengadilan dan Mahkamah Agung;

2. Untuk lebih memberikan akses keadilan bagi para pihak dengan proses yang cepat sederhana dan biaya murah;

3. Untuk memberikan penyelesaian yang benar-benar tuntas, dalam arti tidak hanya tuntas secara hukum, namun juga tuntas secara sosial dan moral.

4. Untuk memberikan kepastian hukum bagi para pihak atas kesepakatan damai yang telah dilakukan?.

Mediasi merupakan salah satu bentuk dari alternatif penyelesaian sengketa di luar pengadilan. Tujuan dilakukan mediasi adalah menyelesaikan sengketa antara para pihak dengan melibatkan pihak ketiga yang netral dan imparsial. PERMA Nomor 1 Tahun 2016 telah memperkuat kewajiban-kewajiban yang sebelumnya tidak diatur

6 Angga Juniarta, Ida Bagus Gede, Legalitas Rekaman Circuit Closed Television (CCTV) Dalam Proses Pembuktian di Persidangan, Udayana Master Law Journal, Volume 7, No. 1, 2018, Universitas Udayana.

7 Witanto, D. Y. (2011). Hukum acara mediasi: dalam perkara perdata di lingkungan peradilan umum dan peradilan agama: menurut PERMA no. 1 tahun 2008 tentang prosedur mediasi di pengadilan. Bandung: Alfabeta. h. 56. 
secara jelas di dalam HIR dan RBg, misalnya di dalam PERMA Nomor 1 Tahun 2016 Pasal 3 ayat (1) mewajibkan agar di dalam pertimbangan putusan, hakim harus menyebutkan bahwa perkara tersebut telah diupayakan perdamaian lewat proses mediasi, namun tidak berhasil dengan mencantumkan nama mediator untuk perkara yang bersangkutan, berdasarkan penetapan penunjukkan mediator. Hal ini tidak dijumpai di dalam HIR dan RBg, bahkan di dalam pasal $130 \mathrm{HIR}$ atau $154 \mathrm{RBg}$ tidak terdapat kata wajib dalam menjalani proses perdamaian.

Mediasi dapat mengantarkan para pihak pada perwujudan kesepakatan damai yang permanen dan lestari, mengingat penyelesaian sengketa melalui mediasi menempatkan kedua belah pihak pada posisi yang sama, tidak ada pihak yang dimenangkan atau pihak yang dikalahkan (win-win solution) ${ }^{8}$. Dengan demikian, unsur-unsur esensial mediasi, yaitu:

1. Mediasi merupakan cara penyelesaian sengketa melalui perundingan berdasarkan pendekatan mufakat atau konsensus para pihak;

2. Para pihak meminta bantuan pihak lain yang bersifat tidak memihak yaitu mediator;

3. Mediator tidak memiliki kewenangan memutus, tetapi hanya membantu para pihak yang bersengketa dalam mencari penyelesaian yang dapat diterima para pihak 9 .

Mengingat pasal 130 HIR dan pasal 154 RBg menyebutkan bahwa "Jika pada hari yang telah ditentukan para pihak datang menghadap, maka pengadilan negeri dengan perantaraan ketuanya akan berusaha memperdamaikan mereka". Tujuan diterbitkannya PERMA Nomor 1 Tahun 2016 bukan untuk membangun suatu lembaga hukum yang baru, melainkan hanya sekedar memberikan aturan teknis terhadap lembaga damai yang sebelumnya telah diatur di dalam HIR dan RBg dan substansinya tetap berpedoman pada aturan pokok yang menjadi sumbernya.

\subsection{Kekuatan Hukum Mediasi Selama Proses Penyelesaian Sengketa Perdata Di Pengadilan}

Proses Mediasi merupakan tahapan dimana Mediator memulai melakukan proses Mediasi dengan ruang lingkup yang tidak terbatas hanya pada posita dan petitum gugatan. Mediasi bersifat rahasia, sehingga Mediator Hakim atau Mediator harus segera memusnahkan dokumen-dokumen Mediasi setelah selesainya Mediasi tersebut. Batasan waktu Mediasi adalah 30 hari terhitung sejak penetapan perintah Mediasi, hal ini dapat dilihat dalam pasal 24 ayat (2). Mediasi dapat diperpanjang 30 hari atas dasar persetujuan para pihak dan perpanjangan harus dimintakan kepada Hakim Pemeriksa Perkara, yang tercantum dalam Pasal 24 ayat (3) PERMA Nomor 1 Tahun 2016.

Dilihat dari sifatnya yang konsensual atau mufakat dan kolaboratif, mediasi selalu menghasilkan penyelesaian sengketa dengan cara menang-menang bagi para pihak (win-win solution), sehingga tidak merugikan para pihak yang berperkara. Mediasi termasuk di dalam salah satu alternatif penyelesaian sengketa yang relatif murah dan

8 Rahmadi, T. (2010). Mediasi: Penyelesaian sengketa melalui pendekatan mufakat. Jakarta: Rajawali Pers. h.12.

9 Ibid. 
tidak memakan waktu yang cukup lama jika dibandingkan dengan berperkara melalui proses litigasi. Disamping itu hasil yang didapat selama menempuh proses mediasi yaitu kesepakatan bersama oleh para pihak, sehingga para pihak yang bersengketa tidak mengajukan keberatan atas apa yang telah disepakati.

Tahapan Proses Mediasi merupakan tahapan yang bersifat informal dalam arti tidak secara berurutan diatur di dalam PERMA Nomor 1 Tahun 2016, namun ada beberapa tahapan yang secara kebiasaan dilakukan. Pada pertemuan pertama Mediasi para pihak dijelaskan kembali terkait ketentuan-ketentuan Mediasi dan juga disepakati aturan Mediasi oleh para pihak hal ini terkait pertemuan-pertemuan Mediasi berikutnya atau persiapan jadwal pertemuan Mediasi. Kesepakatan para pihak dan mediator ini tidak diatur secara berurutan di dalam PERMA Nomor 1 Tahun 2016, namun ada beberapa hal yang diatur di dalam PERMA tersebut, antara lain pada Pasal 24 PERMA Nomor 1 Tahun 2016 yakni dalam waktu paling lambat 5 (lima) hari sejak penetapan Mediator maka para Pihak dapat menyerahkan Resume Perkara kepada Mediator dan Pihak lain. Resume Perkara ini berisikan mengenai duduknya perkara dan apa penyelesaian atau upaya perdamaian yang dicari. Penyerahan Resume Perkara dimaksud bertujuan agar para pihak dan mediator dapat memahami sengketa yang akan di Mediasi. Resume Perkara dapat berisikan Tawaran Penyelesaian Mediasi, yang berupa pokok keinginan dari Para Pihak untuk menyelesaikan Perkara.

PERMA Nomor 1 Tahun 2016 mengenal adanya Kaukus, Kaukus merupakan pertemuan Mediator terhadap salah satu pihak tanpa dihadiri oleh pihak lainnya. Fungsi dari Kaukus ini adalah supaya Mediator dapat mendengar pendapat salah satu pihak secara utuh tanpa adanya tekanan dari pihak lain, membantu para pihak untuk menyalurkan emosi tanpa membahayakan kemajuan Mediasi, memungkinkan mediator menemukan atau menggali informasi tambahan terutama kemungkinankemungkinan penyelesaian sengketa. Namun, Kaukus ini harus diberitahukan kepada pihak lain bahwa Mediator dengan salah satu pihak melakukan Kaukus. Kaukus merupakan suatu cara untuk mencari informasi dari suatu pihak yang tidak dimungkinkan disampaikan apabila dengan adanya pihak lainnya, Kaukus dilakukan karena tidak adanya pengajuan alat-alat bukti dalam Proses Mediasi. pada Pasal 26 PERMA Nomor 1 Tahun 2016 Mediasi dapat melibatkan Ahli dan Tokoh Masyarakat atas dasar persetujuan para pihak. Ahli yang dimaksud dalam PERMA ini tidak dijelaskan secara rinci, sehingga dapat dianalogiakan bahwa ketentuan terkait ahli ini berdasarkan ketentuan peradilan pada umumnya, yaitu orang yang karena pendidikan atau pengalamannya selama kurun waktu yang lama dalam menekuni suatu profesi tertentu.

Setelah mengetahui secara jelas duduk perkara, usulan perdamaian yang diinginkan para pihak, melakukan kaukus kepada para pihak, mendengar keterangan Ahli atau Tokoh Masyarakat jika diperlukan, maka Mediator dapat melakukan identifikasi konflik serta kepentingan-kepentingan para pihak, atas temuan-temuan itu lalu Mediator mencari titik temu atau kesepakatan para pihak dimana tidak ada salah satu pihak yang dimenangkan namun para pihak sama-sama dimenangkan, kemudian Mediator dapat mengusulkan berbagai pilihan pemecahan masalah kepada para Pihak. Setelah tahapan Kaukus dan keterangan Ahli jika diperlukan maka terjadi Negosiasi antara Para Pihak yang ditengahi oleh Mediator. Negosiasi ini bertujuan untuk merumuskan atau mencari kesepakatan akan penyelesaian sengketa, yang nantinya akan dirumuskan menjadi Kesepakatan Perdamaian. Setelah penyampaian 
usulan pemecahan masalah maka dapat terjadi beberapa kemungkinan kesepakatan, antara lain; para pihak sepakat untuk damai; para pihak sepakat untuk melakukan perdamaian untuk sebagian pihak atau Perdamaian Sebagian; ataupun para pihak tidak dapat mencari titik temu kesepakatan perdamaian.

Apabila para pihak mencapai kesepakatan dalam Mediasi, menurut ketentuan Pasal 27 PERMA Nomor 1 Tahun 2016 maka para pihak dengan bantuan Mediator wajib merumuskan kesepakatan secara tertulis dalam Kesepakatan Perdamaian yang ditandatangani oleh para pihak dan Mediator. Kesepakatan Perdamaian merupakan dokumen yang memuat syarat-syarat yang disepakati oleh para pihak guna mengakhiri sengketa yang merupakan hasil dari upaya perdamaian dengan bantuan Mediator. Kesepakatan yang dimaksud tidak boleh bertentangan dengan hukum, ketertiban umum, kesusilaan; merugikan pihak ketiga atau tidak dapat dilaksanakan.

Kesepakatan Perdamaian tersebut dapat diajukan kepada Hakim Pemeriksa Perkara agar dikuatkan menjadi Akta Perdamaian. Hakim Pemeriksa perkara dalam waktu paling lambat 2 (dua) hari harus segera mempelajari dan meneliti kesepakatan. Setelah itu apabila sudah memenuhi ketentuan sebagaimana dimaksud pada Pasal 27, maka dalam waktu paling lama 3 (tiga) hari Hakim Pemeriksa Perkara menerbitkan penetapan hari sidang pembacaan Akta Perdamaian yang terbuka untuk umum. Pasal 1 angka 10 PERMA Nomor 1 Tahun 2016 menyatakan Akta Perdamaian adalah akta yang memuat isi kesepakatan perdamaian dan putusan hakim yang menguatkan kesepakatan perdamaian tersebut. Keberadaan Akta Perdamaian ini sebagai penguat dari Kesepakatan Perdamaian antara Para Pihak, yang mana Akta Perdamaian ini memiliki kekuatan Eksekutorial layaknya Putusan Pengadilan.

Dasar Kesepakatan Perdamaian memiliki kekuatan Eksekutorial layaknya Putusan Pengadilan berdasarkan dari adanya asas pacta sunt servanda. Pacta sunt servanda merupakan asas atau prinsip dasar dalam sistem hukum civil law yang berkaitan dengan kontrak atau perjanjian yang dilakukan diantara para individu, yang mengandung makna bahwa perjanjian merupakan undang-undang bagi para pihak yang membuatnya, yang tercantum dalam Pasal 1338 Kitab Undang- Undang Hukum Perdata, yang berbunyi "Semua perjanjian yang dibuat secara sah berlaku sebagai undang-undang bagi mereka yang membuatnya".

Perdamaian Sebagian dicapai dalam hal terjadi kesepakatan antara penggugat dan sebagian pihak tergugat, yang mana penggugat mengubah gugatan dengan tidak lagi mengajukan pihak tergugat yang telah mencapai kesepakatan perdamaian sebagian. Seperti halnya dalam kesepakatan perdamaian, penggugat dan tergugat yang berdamai membuat kesepakatan perdamaian yang kemudian akan dikuatkan dengan Akta Perdamaian. Kemudian dalam hal para pihak mencapai kesepakatan atas sebagian dari seluruh objek sengketa atau tuntutan, maka kesepakatan atas sebagian objek sengketa tersebut dibuat kesepakatan perdamaian yang kemudian juga akan dikuatkan dengan Akta Perdamaian. Maka dalam hal tersebut, dalam sidang lanjutan Hakim Pemeriksa Perkara hanya akan memeriksa objek sengketa yang belum berhasil disepakati oleh para pihak.

Prinsip dasar (basic principle) adalah landasan filosofis dari diselenggarakannya kegiatan mediasi. Prinsip atau filosofi ini merupakan kerangka kerja yang harus diketehaui oleh mediator, sehingga dalam menjalankan mediasi tidak keluar dari arah filosofi yang melatarbelakangi lahirnya mediasi. David spenser dan Michael Brogan 
merujuk pada pandangan Ruth Carlton tentang lima prinsip dasar mediasi. Lima prinsip ini dikenal dengan lima dasar filsafat mediasi. Kelima prinsip tersebut adalah; prinsip kerahasiaan (confidentiality), prinsip sukarela (volunteer), prinsip pemberdayaan (empowerment), prinsip netralitas (neutrality), dan prinsip solusi yang unik (a unique solution $)^{10}$. Pengertian dari istilah kewajiban secara umum dapat diartikan sebagai segala sesuatu yang harus di lakukan setelah sebelum mendapatkan hak ${ }^{11}$. Apabila para pihak tidak dapat mencapai kesepakatan dalam Mediasi setelah mencapai batas waktu 30 hari atau beserta perpanjangannya, terdapat salah satu pihak yang tidak beritikad baik dalam pelaksanaan medasi maka Mediator wajib menyatakan Mediasi gagal dan memberitahukan kepada Hakim Pemeriksa Perkara.

Mediator dalam melaksanakan tugasnya juga harus mengingat bahwa mediasi bertujuan untuk membantu para pihak mencapai kesepakatan perdamaian. Karena orientasi mediasi sendiri adalah pada hasil berupa para pihak mau menyelesaikan sengketa melalui kesepakatan damai. Tetapi hal itu dilakukan atas kerelaan para pihak, bukan dari paksaan agar berdamai. Karena sepanjang klausul yang disepakati para pihak tidak bertentangan dengan hukum, tidak melanggar hak orang lain serta dapat dilaksanakan maka mediasi pada dasarnya telah terlaksana pada jalur yang benar. Apabila mediasi yang dilakukan gagal, maka mediator dilarang menjadi saksi dalam proses persidangan perkara yang bersangkutan. Dalam hal ini PERMA menempatkan eks-mediator dalam kedudukan tidak cakap menjadi saksi, khusus dalam sengketa tersebut. Namun terhadap perkara lain, tetap cakap menjadi seorang saksi sepanjang tidak bertentangan dengan ketentuan Pasal 145 HIR dan Pasal 1909 BW. Serta segala apa saja yang diajukan, disampaikan, maupun yang diakui oleh para pihak dalam proses mediasi tidak dapat dijadikan sebagai alat bukti sesuai dengan Pasal 164 HIR dan Pasal 1866 BW ${ }^{12}$. Mediator wajib menyatakan Mediasi tidak dapat dilaksanakan beserta melakukan pemberitahuan tertulis kepada Hakim Pemeriksa Perkara. Setelah hal tersebut, maka Hakim Pemeriksa Perkara dapat segera menerbitkan penetapan untuk melanjutkan Sidang Pemeriksaan Perkara sesuai ketentuan Hukum Acara yang berlaku.

\section{Kesimpulan}

Eksistensi mediasi dalam penyelesaian sengketa perdata di pengadilan dalam PERMA No. 1 Tahun 2016 memuat sepuluh prinsip pengaturan tentang penggunaan mediasi terintegrasi di pengadilan (court-connected mediation) yang meliputi mediasi wajib ditempuh, otonomi para pihak, mediasi dengan itikad baik, efisiensi waktu, sertifikasi mediator, tanggung jawab mediator, kerahasiaan, pembiayaan, pengulangan mediasi, kesepakatan perdamaian di luar pengadilan. Penerbitan PERMA Nomor 1 Tahun 2016 bertujuan untuk: Untuk mengatasi penumpukan perkara di pengadilan dan Mahkamah Agung, Untuk lebih memberikan akses keadilan bagi para pihak dengan

10 Haynes, J. M., Haynes, G. L., \& Fong, L. S. (2012). Mediation: Positive conflict management. New York: Suny Press. h. 16.

11 Putra, P. N. B. R. C., \& Landra, P. T. C. Pengaturan Hukum Terhadap Advokat Asing Yang Beracara di Indonesia Ditinjau dari Undang-Undang No 18 Tahun 2003 Tentang Advokat. Jurnal Magister Hukum Udayana (Udayana Master Law Journal), 6(2), 136-152. https://doi.org/10.24843/JMHU.2017.v06.i02.p01

12 Ardhira, A. Y., \& Anand, G. (2018). Itikad Baik Dalam Proses Mediasi Perkara Perdata Di Pengadilan.Media Iuris, 1(2), h. 201. 
proses yang cepat sederhana dan biaya murah, Untuk memberikan penyelesaian yang benar-benar tuntas, dalam arti tidak hanya tuntas secara hukum, namun juga tuntas secara sosial dan moral, Untuk memberikan kepastian hukum bagi para pihak atas kesepakatan damai yang telah dilakukan.

Kekuatan hukum mediasi selama proses penyelesaian sengketa perdata di Pengadilan dilihat dari sifatnya yang konsensual atau mufakat dan kolaboratif, mediasi selalu menghasilkan penyelesaian sengketa dengan cara menang-menang bagi para pihak (win-win solution). Mediasi termasuk di dalam salah satu alternatif penyelesaian sengketa yang relatif murah dan tidak memakan waktu yang cukup lama jika dibandingkan dengan berperkara melalui proses litigasi. Apabila para pihak mencapai kesepakatan dalam Mediasi, menurut ketentuan Pasal 27 PERMA Nomor 1 Tahun 2016 maka para pihak dengan bantuan Mediator wajib merumuskan kesepakatan secara tertulis dalam Kesepakatan Perdamaian yang ditandatangani oleh para pihak dan Mediator. Kesepakatan Perdamaian tersebut dapat diajukan kepada Hakim Pemeriksa Perkara agar dikuatkan menjadi Akta Perdamaian, yang mana Akta Perdamaian ini memiliki kekuatan Eksekutorial layaknya Putusan Pengadilan dengan dasar pertimbangan Pasal 1338 KUHPerdata.

\section{Daftar Pustaka}

\section{Buku}

Djam'an, S., \& Komariah, A. (2010). Metodologi Penelitian Kualitatif. Bandung: Alfabeta.

Haynes, J. M., Haynes, G. L., \& Fong, L. S. (2012). Mediation: Positive conflict management. New York: Suny Press.

Maskur Hidayat, S. H. (2016). Strategi \& Taktik Mediasi. Jakarta: Kencana.

Rahmadi, T. (2010). Mediasi: Penyelesaian sengketa melalui pendekatan mufakat. Jakarta: Rajawali Pers.

Witanto, D. Y. (2011). Hukum acara mediasi: dalam perkara perdata di lingkungan peradilan umum dan peradilan agama: menurut PERMA no. 1 tahun 2008 tentang prosedur mediasi di pengadilan. Bandung: Alfabeta.

\section{Jurnal}

Ardhira, A. Y., \& Anand, G. (2018). Itikad Baik Dalam Proses Mediasi Perkara Perdata Di Pengadilan. Media Iuris, 1(2), 200-214. http://dx.doi.org/10.20473/mi.v1i2.8821

Bintoro, R. W. (2016). Kajian Ontologis Lembaga Mediasi di Pengadilan. Yuridika, 31(1), 121-142. http://dx.doi.org/10.20473/ydk.v31i1.1959

Juniarta, I. B. G. A. Legalitas Rekaman Circuit Closed Television (CCTV) Dalam Proses Pembuktian di Persidangan. Jurnal Magister Hukum Udayana (Udayana Master Law Journal), 7(1), 36-50. https://doi.org/10.24843/JMHU.2018.v07.i01.p04

Matarau, E. H. B. (2017). Penyelesaian Sengketa Melalui Mediasi di dalam Pengadilan. Jurnal Kertha Wicaksana, 1(6).

Putra, P. N. B. R. C., \& Landra, P. T. C. Pengaturan Hukum Terhadap Advokat Asing Yang Beracara di Indonesia Ditinjau dari Undang-Undang No 18 Tahun 2003 
Tentang Advokat. Jurnal Magister Hukum Udayana (Udayana Master Law Journal), 6(2), 136-152. https://doi.org/10.24843/JMHU.2017.v06.i02.p01

Sari, I. M. Persamaan Perlakuan Para Pihak dalam Beracara di KPPU Dalam Perspektif Hukum Acara Peradilan Indonesia. Jurnal Magister Hukum Udayana (Udayana Master Law Journal), 5(2), 380-391. https://doi.org/10.24843/JMHU.2016.v05.i02.p12

\section{$\underline{\text { Peraturan Perundang-undangan }}$}

Kitab Undang- Undang Hukum Perdata (Staatsblaad Nomor 23 Tahun 1847 Tentang Burgerlijk Wetboek) (Staatsblad No. 23 Tahun 1847);

Herziene Inlandsch Reglemen;

Rechtsreglement voor de Buitengewesten;

Undang-Undang Republik Indonesia Nomor 48 Tahun 2009 Tentang Kekuasaan Kehakiman (LN No. : 157, TLN No.: 5076)

Peraturan Mahkamah Agung Republik Indonesia Nomor 1 Tahun 2016 Tentang Prosedur Mediasi di Pengadilan. 